\title{
Gambling and Violence in Hungary
}

\author{
Judit Tessenyi and Peter Kovacs
}

$\mathbf{W}$ HEN WE THINK ABOUT THE IDEA of delinquency, we typically do not associate it with the idea of gambling. However, it seems that the connection between them is becoming closer; hence, it is important to examine it. In the past, people were often not aware that gambling addiction can be the cause of different crimes; however, statistics show a greater rate of prisoners addicted to gambling than members of the general population, suggesting a link between gambling and crimes, including violent crimes.

Since the opportunities for and access to all kinds of gambling are greater than ever before-and are still increasing with online gaming - criminal activity linked to gambling may be increasing, too. In this article, we address this topic via research among prisoners who answered questionnaires.

Although gambling is often accompanied by other psychological illnesses (for example, depression), or other illnesses causing addiction (for example, alcoholism), generally, it has not been connected to delinquency. In this article, we survey the connection between gambling and criminality, a topic of some importance because gambling and the amount of money spent on it has increased in the last few years. The rise in gambling spending can lead to increased criminality. First, if money from legal sources runs out but players continue to gamble, they may use criminal methods to acquire funds. Second, the lifestyle of many problem gamblers results in increased stress and more and more intensive gameplay, increasing anxiety and depression and-sometimes-aggression, leading to criminal acts.

Judit Tessenyi was the regional director of Szerencsejáték Zrt. (Gaming Plc.) in Szeged, Hungary. Peter Kovacs is an associate professor in the Department of Statistics and Demography, Faculty of Economics and Business Administration, at the University of Szeged in Szeged, Hungary.

\section{HYPOTHESES}

Abbott, McKenna, and Giles (2000) found in their surveys that $76 \%$ of the prisoners surveyed had problems with the consumption of alcohol. Compared to this, $61 \%$ of prisoners had problems with gambling. They ascertained also that these individuals' problems with drugs and gambling probably related to the crimes they commited (Gyüre 2004).

Most people think that delinquency (and gambling) is primarily a problem for men; however, this is not necessarily the case (at least not anymore). Women are the fastest growing group with these problems. Overall, the number of people with problems with delinquency and gambling has become four times larger since 1997, growing by $309.7 \%$ (Paton-Simpson, et al. 2002). In New Zealand in 2001, 51.3\% of participants in counselling for problem gambling were women. Furthermore, in the study by Abbott and his colleagues, in women's prisons in New Zealand, one woman of every three was a problem gambler, compared to men's prisons, where the rate is one man of every four. Abbott and McKenna ascertained that "the frequency of violent crimes and crimes against individuals, committed by problematic female gamblers are more likely, than in the case of the ones without gambling problems" (Abbott, McKenna and Giles 2000, p. 61). Additionally, researchers showed that more than half of the women prisoners were problem gamblers who were also struggling with serious alcohol issues. As a whole it seems that the correlation between women, gambling, and crime has been increasing.

Between December 2009 and March 2010, we collected data from three jails concerning the habits, demographic information, and family relationships of 140 prisoners. According to our hypothesis, the ratio of people who are addicted to gambling is 
higher among criminals than among the normal population (the last is $1.2 \%$ ), ${ }^{1}$ and the problem of addiction plays a significant role in committing crimes. We are furthermore hypothesizing that those prisoners who have a problem gambler in the family are more likely to themselves become addicted to gambling. In our analysis, we also examined whether addicted gamblers were aware of the nature of their behavioral problems.

\section{COMMITING CRIMES AND SELF DAMAGE}

In a wider interpretation, self damage, like suicide, is included as a delinquency, which can be related to gambling, and the risk is high not just for gamblers but for their spouses as well. In the report of the Diagnostic and Statistical Manual of Mental Disorders, Fourth Edition, Text Revision (DSM-IV) (American Psychiatric Association 1994), 20\% of attempted suicides (among both women and men) were related to gambling. In some cases, savings and family assets disappeared, causing aggression and depression. Deteriorated social relations, financial decay, despair, and remorse chased the gambler-or a member of the gambler's family-into suicide.

Another issue arises from gamblers seeking to acquire money for gambling. Some gamblers commit crimes to support their gambling when they have run out of ordinary financial resources. Robbery, burglary, and other kinds of theft (e.g., embezzlement from an employer) are the most common crimes. While the motivation to commit these crimes is gambling, there are other aggravating circumstances such as alcohol or other drugs. Other research, also performed in prison, demonstrated that even though alcohol aggravates the problem gambling among those commiting violent crimes, other circumstances can have a deeper influence (Sullivan 2001).

Some crimes of violence are also related to gambling. For example, a winner might be robbed of their money in the parking lot of a casino. Loan sharks give gamblers usurious loans, often in return for exaggerated interest rates and impossible compensation schedules. Being unable to pay back the loan can lead to serious consequences, and a failure to pay is often accompanied by violence, which may force the gambler to hide or to escape.

The seriousness and number of crimes related to gambling are important not only because of their di- rect social expenses, but also the costs associated with the "black market" (e.g., usury, tax evasion, pauperization) - and we still haven't mentioned handling opportunities and recreational expenses.

\section{DOMESTIC VIOLENCE AND GAMBLING}

Domestic violence, which can be triggered by gambling (as well as by other stressors), is often a "hidden" problem because it is accompanied by shame and remorse; as a consequence, it is difficult to examine. There are no easy methods to study this matter, because this behavior is not accepted in most (if any) communities. The problem is most likely a recurring one: even after an abuser suffers legal consequences (if the abuser suffers legal consequences), in the absence of effective psychological and medical treatement, the abuse will repeat itself and become acute. The abuse may be suspended for the time that the perpetrator is imprisoned, if the perpetrator is imprisoned at all, but that is only a temporary reprieve.

\section{VERBAL AND EMOTIONAL ABUSE}

During the survey of this phenomenon, we noticed two interesting elements. The first one is self-verification and self-justification. Although $87 \%$ of addicted gamblers questioned were aware that they were addicted to gambling, they did not consider their behavior dangerous or sick.

In a prison environment, social standing often rises with the severity of the anti-social/criminal acts committed. The risk for this research is that when prisoners fill out the questionnaires, they may exaggerate the money spent on gambling, and also exaggerate the frequency of gameplay. To mitigate this risk, we asked them in private to eliminate "grandstanding" for an audience; also, the substantive and verifying questions were structured in such a way as to reduce exageration in answers.

Verbal and emotional abuse is common among those who are addicted to gambling. Gambling addiction does not always lead to committing crimes, of course; however, financial decay and the consequencies of

\footnotetext{
${ }^{1}$ Ipsos 2010. Ipsos Media, Advertisement, Market and Opinion Research Institute has been considered a dominant player in the Hungarian economic and social research industry.
} 
deteriorated social relations certainly contribute to criminal and other anti-social behavior.

\section{INTERNATIONAL PERSPECTIVE}

\section{Australia}

Jones (1989) conducted research on 60 male prisoners in research in a prison in Canning Vale in West-Australia. He found that $22 \%$ of the inmates were pathological gamblers. Marshall, Balfour, and Kenner (1997) surveyed 103 male prisoners in South Australia. In the sample surveyed, $33 \%$ of prisoners were pathological gamblers, and $8 \%$ of them were problem gamblers.

Abbott, McKenna, and Giles (2000) found that in New Zealand, $43 \%-50 \%$ of male prisoners were addicted to gambling. Abbott and his coauthors (2000) surveyed male prisoners in 94 male prisons in the recent past. According to their results, 33\% of the prisoners were addicted to gambling and $12 \%$ of them were problematic gamblers.

\section{United States of America}

In his earliest study, Roebuck (1967) ascertained that $38 \%$ of 409 prisoners surveyed in a prison in Washington State were permanent gamblers. They spent their free time playing cards and lottery.

In a later survey in two prisons in New Jersey, Lesieur and Klein (1985) ascertained that $30 \%$ of the 448 prisoners showed signs of being pathological gamblers, in the same proportion in males and females. In addition, $23 \%$ of males and $28 \%$ of females were recidivist gamblers.

Anderson (1999) had 233 male prisoners in four Central-Western American prisons fill out the South Oaks Gambling Screen (SOGS) questionnaire (Lesieur and Blume, 1987) (see below) in order to measure the incidence of problem gambling. His results showed that $35 \%$ of them were endangered gamblers and $38 \%$ of them were pathological gamblers. Twenty percent of them reported that they had committed malfeasance to be able to pay their gambling debts and/or spend money on gambling.

\section{RESEARCH IN HUNGARY 2010}

\section{Methodology}

The SOGS questionnaire (see Appendix A) is perhaps the world's best-known and most commonly used questionnaire. It consists of 20 theorems based on DSM-IV criteria (Appendix A is available in the online article at www.liebertpub.com/glre).

A problem gambler (in our test we also call this category endangered) is someone who provides three or four yes answers. If a person has a pathological addiction to gambling (addicted), than he gets five points or more.

A person with pathological addiction to gambling has a more serious problem than a problem gambler. Pathological addiction to gambling is classified as an impulse control disorder by DSM-IV (1994). Pathological addiction to gambling is generally considered a life-long problem. However, some reseachers (for example Williams et al. 2005 and Volberg 1999) later acknowledged that it can be a transitional state, too. The newer versions of SOGS, in general, cover 6 or 12 months, so the tests that were completed some years later can show completely different results in the case of the same person.

DSM-IV ${ }^{2}$ is an easily usable guide. It lists 10 criteria used medically to diagnose addiction to gambling; if 5 of these 10 conditions are realized, we are speaking about an addicted patient, in the medical sense.

The problem with surveys like the SOGS is that when people are asked about their gambling habits, many them don't give honest or accurate answers, either due to feelings of shame, or because they are not aware of their own gambling habits and how they affect their lives. For example, according to an Australian survey, $30 \%$ of former addicted gamblers said that if they had been asked about their gambling habits while they were addicted, they would have lied.

\section{Demographic features of the persons surveyed}

The responses of 125 males and 10 females in regards to demographics surveyed are included in

${ }^{2}$ Diagnostic and Statistical Manual of Mental Disorders (DSM). The American Psychiatric Association (APA), edits it. Its purpose is to help doctors use symptoms to diagnose mental illness; it also assigns diagnostic codes to the illnesses. It has been published in successive editions, because the science of medicine is constantly developing. The concept underlying categorizing and classifying is that similar symptoms will be indicative of similar conditions. The use of standardized referrants also improves communication between experts. The best treatment(s) can, in theory, be determined based on symptomology. However we should not ignore the fact that every case is unique. The procession of the illness can not be predicted $100 \%$, and the same symptomes do not invariably flow from the same illness. 
the compiled questionnaires (5 did not respond). From the 140 questionnaires that can be compiled, 21 people were divorced while 65 were unmarried, widowed, or single; 35 were married; and 19 didn't answer this question. Furthermore, 61 of them finished elementary school as their highest education; 27 of them passed the final exam; and 9 of them graduated college or university (10 of them didn't answer).

In the case of age groups, the relation is significant: $56 \%$ of addicts are between the ages of 18 and 30 , while the distribution of non-addicts is even. Thirty-six percent of the endangered persons are under the age of 18 (Figure 1).

According to our SPSS analyses, there is no significant relation between education and gambling addiction. Nonetheless, $68 \%$ of addicts finished only elementary school (few graduated).

Family status and the number of children did not show a significant relation to gambling addiction, though divorced persons and singles evidently become addicted more easily.

Of the persons surveyed, $60.7 \%$ had at least one family member who was or is addicted. However, the gambling habits of their mothers and siblings do not show a significant relation to the illness of addiction.

\section{Relation of criminality and gambling addiction}

The 140 prisoners surveyed were imprisoned because of the following reasons (Table 1):

With the cross-table method we surveyed, one by one, how significantly the reason for imprisonment relates to gambling addiction. Before that we counted, according to the questions of SOGS, how

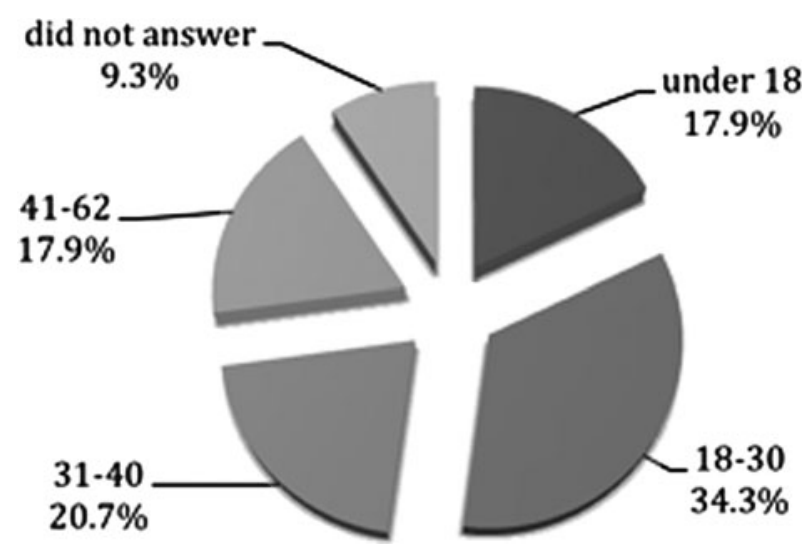

FIG. 1. Age partition of the surveyed population.
TABle 1. REASONS FOR IMPRISONMENT

\begin{tabular}{lc}
\hline Cause of imprisonment & Number of prisoners \\
\hline Burglary & 12 \\
Physical violence & 25 \\
Robbery & 45 \\
Stealing & 26 \\
Truculence & 9 \\
Other & 47 \\
\hline
\end{tabular}

many people of the surveyed group were addicted or endangered (Figure 2).

It can be seen from our results that gambling is not a problem for only 45 people out of the 138 . As to the rest, $30.7 \%$ are endangered, which means they answered "yes" to the first four relevant questions; $35.7 \%$ were addicted (50 people), which means that they answered "yes" to five or more questions. In the latter group, 11 people were on the boundary-they had exactly five "yes" answers. However, the others, who had more "yes" answers, clearly showed the signs of addiction, so in our latter survey, we split addicted persons into two other sub-groups by the method of cluster-analysis.

It should be mentioned, that the survey by IPSOS in early 2010 used the Canadian Problem Gambling Index (CPGI) questionnaire (Ferris and Wayne, 2001). Among the total population of Hungary, $1.2 \%$ were addicted and $9.5 \%$ were endangered. In Hungary, this was the largest survey about gambling habits and gambling addiction.

Altogether, $1 \%$ of them violated the law to pay for gambling.

In our surveys, $12.1 \%$ of the prisoners surveyed admitted that their addiction to gambling played a role in their criminality (Table 2 ).

Burglary and physical violence did not show a significant relation to gambling addiction. However $60 \%$ of the persons imprisoned for theft were addicted; this is twice the rate of those imprisoned for something else.

Of those surveyed, $50.7 \%$ were repeat offenders. According to the SOGS survey, $51 \%$ of the repeat offenders were addicted to gambling, but $45 \%$ of first offenders were non-problematic and $40 \%$ were endangered. Consequently, it is three times more likely that repeat offenders will be addicted to gambling.

Other addictions include alcohol and drugs. As we anticipated, many persons surveyed did not answer questions relating to these addictions (46.4\%). 


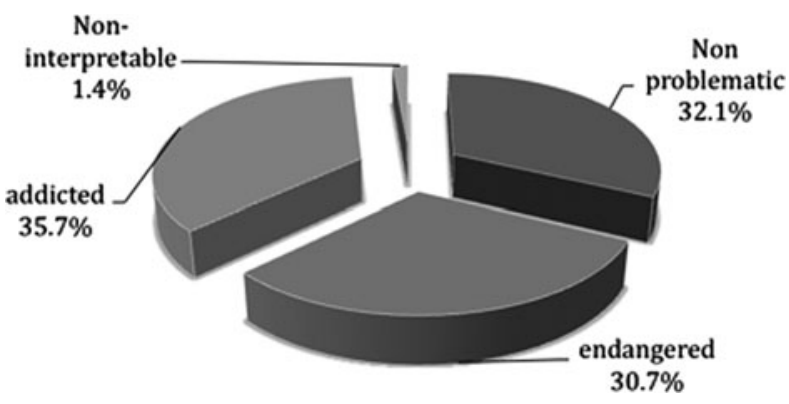

FIG. 2. Addiction to gambling among the surveyed prisoners. Gambling addiction according to the South Oaks Gambling Screen (SOGS).

However, $13 \%$ of those who responded admitted problems with alcohol, while $19.3 \%$ admitted to drug problems (Table 3). Furthermore, $74 \%$ of the latter are addicted to gambling according to the SOGS categorization, but the low number of participants does not let us draw any conclusions, despite the significant relations.

\section{Further cross-table analysis}

We have surveyed whether family status affects the addicted gambler. That is, how much does the fact that there is a family member addicted to gambling determine the formation of gambling addiction? We found that although there is a relation between them, the relation is not significant.

$92 \%$ of the gamblers spend more than Hungarian forint (HUF) 5,000 on gambling every week; $74 \%$ of them spend more than HUF 10,000; and $44 \%$ spend more than HUF 100,000.

$40 \%$ of non-problematic gamblers never gamble. $78 \%$ of them spend a maximum of HUF 1,000 on gambling every week, and only $8.8 \%$ of them spend more than HUF 5,000.

$30 \%$ of endangered persons spend from HUF 5,000 to HUF 10,000 on gambling weekly; $44 \%$ of them spend between HUF 1,000 and HUF 10,000.

Table 2. Did the Addiction to Gambling Play a Role in One's CRiminality?

\begin{tabular}{|c|c|c|c|c|c|}
\hline & & Frequency & Percent & $\begin{array}{c}\text { Valid } \\
\text { percent }\end{array}$ & $\begin{array}{c}\text { Cumulative } \\
\text { percent }\end{array}$ \\
\hline Valid & $\begin{array}{l}\text { Yes } \\
\text { No } \\
\text { Total }\end{array}$ & $\begin{array}{r}17 \\
119 \\
136\end{array}$ & $\begin{array}{l}12.1 \\
85.0 \\
97.1\end{array}$ & $\begin{array}{r}12.5 \\
87.5 \\
100.0\end{array}$ & $\begin{array}{r}12.5 \\
100.0\end{array}$ \\
\hline $\begin{array}{l}\text { Missing } \\
\text { Total }\end{array}$ & System & $\begin{array}{r}4 \\
140\end{array}$ & $\begin{array}{r}2.9 \\
100.0\end{array}$ & & \\
\hline
\end{tabular}

Table 3. Gambling Types Related to Drug Use

\begin{tabular}{|c|c|c|c|c|}
\hline & $\begin{array}{l}\text { No problem } \\
\text { gambler }\end{array}$ & Endangered & $\begin{array}{l}\text { Problem } \\
\text { gambler }\end{array}$ & Total \\
\hline \multicolumn{5}{|l|}{ Drug } \\
\hline \multicolumn{5}{|l|}{ Yes } \\
\hline Count & 2 & 5 & 20 & 27 \\
\hline $\begin{array}{l}\text { \% within } \\
\text { drug }\end{array}$ & $7.40 \%$ & $18.50 \%$ & $74.10 \%$ & $100.00 \%$ \\
\hline $\begin{array}{c}\% \text { within } \\
\text { game }\end{array}$ & $11.80 \%$ & $27.80 \%$ & $50.00 \%$ & $36.00 \%$ \\
\hline \multicolumn{5}{|l|}{ No } \\
\hline Count & 15 & 13 & 20 & 48 \\
\hline $\begin{array}{l}\text { \% within } \\
\text { drug }\end{array}$ & $31.30 \%$ & $27.10 \%$ & $41.70 \%$ & $100.00 \%$ \\
\hline $\begin{array}{c}\% \text { within } \\
\text { game }\end{array}$ & $88.20 \%$ & $72.20 \%$ & $50.00 \%$ & $64.00 \%$ \\
\hline \multicolumn{5}{|l|}{ Total } \\
\hline Count & 17 & 18 & 40 & 75 \\
\hline $\begin{array}{l}\text { \% within } \\
\text { drug }\end{array}$ & $22.70 \%$ & $24.00 \%$ & $53.30 \%$ & $100.00 \%$ \\
\hline $\begin{array}{l}\text { \% within } \\
\text { game }\end{array}$ & $100.00 \%$ & $100.00 \%$ & $100.00 \%$ & $100.00 \%$ \\
\hline
\end{tabular}

\section{Gambling types related to gambling addiction}

Question: whether the type(s) of gambling is (are) related to gambling addiction? Using the SOGS categorization, we surveyed gambling types one-by-one, based on the cross-table analysis, searching for a significant relation. The cross-tables of the gambling types are shown in Appendix B. (Appendix B is available in the online article at www.liebertpub.com/glre) According to our survey raffle ticket, arcade poker machines, and casinos cause most of the addiction to gambling (Table 4).

Playing cards shows a significant relation to the formation of gambling addiction; $61 \%$ of persons who play cards more times a week are addicted, while $21.9 \%$ of those who do not play cards are addicted to some other kind of gambling.

We also found a significant relation between sport betting and the addiction to gambling: $77 \%$ of those who bet more times a week are addicted.

Table 4. Gambling Habits of Persons Surveyed

\begin{tabular}{lccc}
\hline Game & & $\begin{array}{c}\text { Gambling addicts } \\
\text { can share levels } \\
\text { among the } \\
\text { type }\end{array}$ & $\begin{array}{c}\text { Gambling } \\
\text { addicts how } \\
\text { likely is game }\end{array}$ \\
card & 0.002 & 61.1 & played weekly (\%) \\
casino & 0 & 88.9 & 32.4 \\
lottery & 0.012 & 60 & 41 \\
machine & 0 & 76.7 & 38.5 \\
\hline
\end{tabular}


Interestingly, we did not find a close relation between addiction and those who play in casinos. Nevertheless, arcade machines showed a close and obvious relation to gambling addiction: $60 \%$ of those who are addicted to gambling admitted to playing arcade machine more times a week.

\section{Cluster analysis}

We used cluster analysis (multi-variable analysis techniques) to order respondents into groups. Our goal was to create groups, such that their elements are attached as tightly as possible and are relatively different from the elements of other clusters (Falusi and Ollé 2000). The groups are classified by their differences and by their similarities. The measure of similarity is determined by the distance of the object pairs (Hajdu 2003).

Since we know the number of clusters to be created, and we can confirm it with the accepted theorems, we applied the so-called two-step cluster analysis, from the well-known cluster-creating methods. SPSS suggested to separate four clusters, that being the optimal number of clusters (Table 5). Accordingly, we chose the following names for the clusters:

- Non-problematic

- Endangered

- "Those ones, who sacrifice everything"

- "Civilizated addiction" (self-controllable)

Among the above clusters, the Non-problematic and Endangered clusters need less explanation: more than one third of the Non-problematic group (36\%) never gambles, the others play only with little money, and gambling does not play a role in their lifestyle. In the Endangered group, more money is spent; and this is the biggest difference between the Endangered and Non-problematic groups. Some of those in the Endangered cluster already have signficant gam-

Table 5. The Number of Objects in the Same Cluster, in the Case of Four Clusters

\begin{tabular}{lccc}
\hline $\begin{array}{l}\text { Cluster } \\
\text { identification } \\
\text { number }\end{array}$ & Ratio (\%) & $\begin{array}{l}\text { Number } \\
\text { of people }\end{array}$ & Name of cluster \\
\hline 4 & 32.5 & 39 & $\begin{array}{c}\text { Non-problematic } \\
\text { "Civilizated addiction" } \\
\text { (self-controllable) } \\
2\end{array}$ \\
27.5 & 33 & 11 & $\begin{array}{c}\text { Those ones, who } \\
\text { sacrifice everything" } \\
\text { Endangered }\end{array}$ \\
3 & 9.2 & 37 & \\
\hline
\end{tabular}

bling debt and have sold belongings or assets to spend money on gambling (8.1\%).

According to SOGS, those who are addicted to gambling can be split into two separate groups: the so-called self-controllable (Civilized addiction) group is not likely to play with gambling debt, although they do play with more money than the Endangered persons. Notwithstanding the above, they did ask for money from loan sharks $(24.2 \%)$, used their credit card(s) (42.4\%), and also sold their property to acquire money for gambling $(60.6 \%)$. The group of "Those ones, who sacrifice everything" went further than this: $54.5 \%$ of them have spent more than HUF 100,000 on gambling at least once in their life, $90.9 \%$ of them used their credit cards to get money for gambling, $81.8 \%$ of them asked for money from loan sharks, and $63.6 \%$ of them sold property to get money for gambling. Further features of clusters are shown in Appendix B.

As part of our research, we wondered whether someone who is addicted to gambling (according to SOGS) considers himself or herself addicted to gambling (i.e., do they know that about themselves- that they are addicted to gambling?); $60 \%$ of addicts considered themselves addicted, and of those who did not consider themselves addicted, one-third were problematic and one-third were endangered.

\section{CONCLUSION}

According to our survey, gambling and gambling addiction can be related to delinquency, so it is important to examine the consequences of gambling addiction. The escalation of opportunities to gamble, the increase in gambling variety, and the availability of new technologies and modalities all contribute to addiction. This results in the growth of mental health problems which can include different kinds of abusive behaviors (and even suicide attempts). Therefore, it is important to take cognizance of the relation between gambling and criminality; it is also important to support the creation of facilities for treating this problem. The best therapeutic practices should be introduced for those who are pathologically addicted to gambling, and for their family members as well.

Further conclusions:

- The four category classifications of CPGI tests are more appropriate to measure addiction to gambling (SPSS also suggests four clusters). 
- Online gambling and strategic computer games can be very interesting, even compelling, for those addicted to gambling. Therefore, it is worthy to expand the research horizon to this area as well.

- A family history of gambling addiction does not determine addiction, but at the same time, it does play a contributory role. Hence, with families where the addiction appears, we should pay attention to protect juvenile family members.

The Hungarian Criminological Association (Magyar Kriminológiai Társaság) surveyed the social, legal, and moral questions of gambling in 1993: "Because gambling fills social needs around the whole world, and this is confirmed not only by the frequently visited casinos, but also by the popular so-called TOTÓ-LOTTÓs, and stakes races in our country. Beside the fulfilment of social needs, another cause of organizing these gambling games, is that it can produce a great income. The laws regarding gambling in our country are primarily financial, and it does not deal with its' criminal effects." (Sebes, 1993).

That conception of the demonstration is quite interesting, which enlightens the philosophical differences of organizing gambling, among welfare states and among those countries, where the democratic change is accompanied by deteriorating financial conditions. The review of Kubinyi Sándor covered primarily the criminal and criminological issues of gambling, analysing those factors, that allow laundering of the so called "black money" by gambling. In the two demonstrations the reader can realize the economical and financial issues of this particular area, that shows that civil services are not prepared for the consequences of the fast spreading gambling games. ${ }^{3}$

\section{REFERENCES}

Abbott, Max W., Brian G. McKenna, and Lynne C. Giles (2000). Gambling and Problem Gambling among Recently Sentenced Males in Four New Zealand Prisons. Wellington, New Zealand: Department of Internal Affairs.
Anderson, D. B. (1999). "Problem Gambling among Incarcerated Male Felons," Journal of Offender Rehabilitation 29(3-4), 113-127.

American Psychiatric Association (1994). Diagnostic and Statistical Manual of Mental Disorders, Fourth Edition (DSM-IV).

Falusi, I. and Ollé, J. (2000). Statisztikai Módszerek Pedagógusok Számára. Budapest: Okker Kiadó Kft.

Ferris, J. and H. Wynne (2001). The Canadian Problem Gambling Index. Ottawa, ON: Canadian Centre on Substance Abuse.

Gyüre, Tamás (2004). Az alexithymia és az alkoholbetegség kapcsolatának vizsgálata, szakdolgozat Debrecen (Debrecen thesis).

Hajdu, Ottó (2003). Többváltozós statisztikai számitások. Statisztikai módszerek a társadalmi és gazdasági elemzésekben. Budapest: Központi Statisztikai Hivatal.

Jones, G. (1989). The Prevalence and Characteristics of Prisoners with Gambling Related Problems in Canning Vale Remand Centre. Perth, WA: Department of Corrective Services.

Lesieur, H. and R. Klein (1985). Prisoners, Gambling and Crime. Paper presented at the Annual Meeting of the Academy of Criminal Justice Sciences, Las Vegas.

Lesieur, H.R. and S.B. Blume (1987). "The South Oaks Gambling Screen (SOGS): A New Instrument for the Identification of Pathological Gamblers." American Journal of Psychiatry 144(9): 1184-1188.

Marshall, M., R. Balfour, and A. Kenner (1997). Pathological Gambling: Prevalence, Type of Offense, Comorbid Psychopathology and Demographic Characteristics in a Prison Population (Submission to the Australian Productivity Commission). Available at http://www.pc.gov.au/inquiry/ gambling/subs/sublist.html.

Paton-Simpson, G.R., M.A. Gruys, and J.B Hannifin (2002). Problem Gambling Counselling in NZ: 2001 National Statistics. Problem Gambling Committee, Wellington, NZ.

Roebuck, J. (1967). Criminal Typology: The Legalistic, Physical-Constitutional-Heredity, PsychologicalPsychiatric, and Sociological Approaches. Springfield, IL: Charles C. Thomas.

${ }^{3}$ Criminological Announcement Archivum: <http://www .kriminologia.hu/default.asp?uid=F3BCE12B-8B2A-464A-95B3E0AE0DE7AD08 > . 
Sebes P. (1993). "A szerencsejátékok társadalmi hatásai Magyarországon.” In: Lévay M. (szerk.), Jóvátétel mint a konfliktusfeloldó igazságszolgáltatás egyik formája. A bünte öteljárási jog re-formja elé. A szerencsejáték társadalmi hatásai Magyarországon. Kriminológiai Közlemények. 48. Magyar Kriminológiai Társaság. Budapest.

Sullivan, Sean (2001). "Gambling Problems in a Prison Population: Prevalence, Recidivism and
Screening," Culture and the Gambling Phenomenon, 340.

Williams, R. J., J. Royston, and B. F. Hagen (2005). "Gambling and Problem Gambling Within Forensic Populations: A Review of the Literature," Criminal Justice and Behavior 32(6): 665-689.

Volberg R. (1999). Gambling and Problem Gambling in Oregon. Report prepared for the Oregon Gambling Addiction Treatment Foundation

\section{APPENDIX A}

Appendix A. South Oak Gambling Screen Questionnaire

Please circle the correct answer

1. Personal Data

Gender woman man

Age

$18-30$

$31-35$

$36-40$

$41-62$

63 and over

Education General Vocational College Graduation

Marital status married divorced widowed/single

$0 \quad 1$

The number of dependents in the household 0

$2 \quad 2+$

2. Information of the Detention

Why are you now here?

Burglary

Physical violence

Robbery

Stealing

Truculence

Other

Do you have previous convictions? yes no

Are you addicted? yes no

If there was (is) an addiction, type:

alcohol drugs gambling other

Before starting your sentence, were you working? yes no

Did you have help for transition after your sentence was over? yes no

Did gambling play a role in the punishable offense? yes no

3. Please indicate which of the following types of gambling you have done in your lifetime. For each type, mark one answer: "Not at All," "Less than Once a Week," or "Once a Week or More."

a. Played cards for money

b. Bet on horses, dogs, or other animals (at OTB, the track, or with a bookie

c. Bet on sport (parlay cards, with bookie at Jai Alai)

d. Played dice games, including craps, over and under, or other dice games 
e. Went to casinos (legal or otherwise)

f. Played the numbers or bet on lotteries

g. Played bingo

h. Played the stock and/or commodities market

i. Played slot machines, poker machines, or other gambling machines

j. Bowled, shot pool, played golf, or some other game of skill for money

k. Played pull tabs or "paper" games other than lotteries

1. Some form of gambling not listed above (please specify:

4. What is the largest amount of money you have ever gambled with on any one day?

I never gambled

HUF 100 or less

More than HUF 100 up to HUF 1,000

More than HUF 1,000 up to HUF 5,000

More than HUF 5,000 up to HUF 10,000

More than HUF 10,000 up to HUF 100,000

More than HUF 100,000

5. Check which of the following people in your life has (or had) a gambling problem.

Father

Brother/Sister

Child(ren)

A Friend or Someone Important in My Life

6. When you gamble, how often do you go back another day to win back money you have lost? Never

Most of the Time I Lose

Some of the Time (less than half the time I lose)

Every Time I Lose

7. Have you ever claimed to be winning money gambling, but weren't really? In fact, you lost? Never Yes, less than half the time I lost Yes, most of the time

8. Do you feel you have ever had a problem with betting or money gambling? No

Yes

Yes, in the past, but not now

Did you ever gamble more than you intended to? yes no

Have people criticized your betting or told you that you had a problem, regardless of whether or not you thought it was true? yes no

Have you ever felt guilty about the way you gamble, or what happens when you gamble? yes no

Have you ever felt like you would like to stop betting money on gambling, but didn't think you could? yes no

Have you ever hidden betting slips, lottery tickets, gambling money, IOUs, or other signs of betting or gambling from your spouse, children or other important people in your life? yes no

Have you ever argued with people you live with over how you handle money? yes no

(If you answered "Yes" to question 12) Have money arguments ever centered on your gambling? yes no

Have you ever borrowed from someone and not paid them back as a result of your gambling? yes no

Have you ever lost time from work (or school) due to betting money or gambling? yes no

If you borrowed money to gamble or to pay gambling debts, who or where did you borrow from (circle

"Yes" or "No" for each): 
- From household money yes no

- From your spouse yes no

- From other relatives or in-laws yes no

- From banks, loan companies, or credit unions yes no

- From credit cards yes no

- From loan sharks yes no

- You cashed in stocks, bonds or other securities yes no

- You sold personal or family property yes no

- You borrowed on your checking accounts (passed bad checks) yes no

- You have (had) a credit line with a bookie yes no

- You have (had) a credit line with a casino yes no

Source: http://www.ncrg.org/sites/default/files/uploads/docs/monographs/sogs.pdf

\section{APPENDIX B}

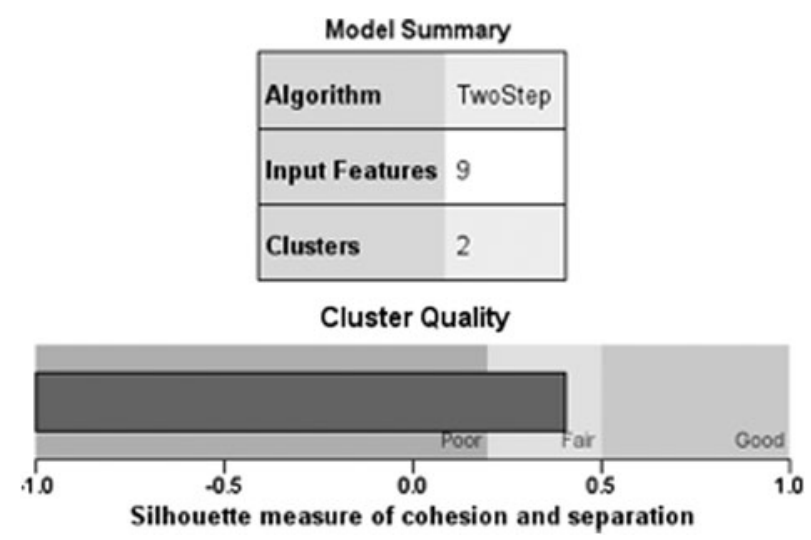

FIG. B1. Cluster quality and measure of separation.

Table B1. Cluster Analysis

\begin{tabular}{|c|c|c|c|}
\hline \multicolumn{4}{|c|}{ Cluster } \\
\hline 1 & 2 & 3 & 4 \\
\hline $32.5 \%(39)$ & $30.8 \%$ & $27.5 \%(33)$ & $9.2 \%(11)$ \\
\hline $\begin{array}{l}\text { addiction non problematic } \\
\quad(100.0 \%)\end{array}$ & $\begin{array}{l}\text { addiction endangered } \\
(83.8 \%)\end{array}$ & $\begin{array}{l}\text { addicted to gambling } \\
(97.0 \%)\end{array}$ & $\begin{array}{l}\text { addiction illness of } \\
\text { addiction }(81.8 \%)\end{array}$ \\
\hline $\begin{array}{l}\text { playing with gambling- } \\
\text { debt in casino }(100.0 \%)\end{array}$ & $\begin{array}{l}\text { playing with gambling- } \\
\text { debt in casino }(94.6 \%)\end{array}$ & $\begin{array}{l}\text { playing with gambling- } \\
\text { debt in casino }(97.0 \%)\end{array}$ & $\begin{array}{l}\text { playing with gambling- } \\
\text { debt in casino }(100.0 \%)\end{array}$ \\
\hline $\begin{array}{l}\text { amount of money never } \\
(42.6 \%)\end{array}$ & $\begin{array}{c}\text { amount of money } 5,001- \\
10,000(27.0 \%)\end{array}$ & $\begin{array}{l}\text { amount of money } 100,001 \\
\quad(42.4 \%)\end{array}$ & $\begin{array}{l}\text { amount of money } 100,001 \\
\quad(54.5 \%)\end{array}$ \\
\hline credit card not $(100.0 \%)$ & credit card not $(100.0 \%)$ & $\begin{array}{l}\text { credit card not } \\
\quad \text { reference }(57.6 \%)\end{array}$ & credit card not $(90.9 \%)$ \\
\hline $\begin{array}{l}\text { playing with gambling- } \\
\text { debt at bookmaker not } \\
(100.0 \%)\end{array}$ & $\begin{array}{l}\text { playing with gambling- } \\
\text { debt at bookmaker not } \\
(97.3 \%)\end{array}$ & $\begin{array}{l}\text { playing with gambling- } \\
\text { debt at bookmaker not } \\
(100.0 \%)\end{array}$ & $\begin{array}{l}\text { playing with gambling- } \\
\text { debt at bookmaker } \\
(63.6 \%)\end{array}$ \\
\hline loan shark not $(100.0 \%)$ & loan shark not $(100.0 \%)$ & loan shark not $(75.8 \%)$ & loan shark yes $(81.8 \%)$ \\
\hline $\begin{array}{l}\text { selling of property not } \\
\quad(100.0 \%)\end{array}$ & $\begin{array}{l}\text { selling of property not } \\
\quad(91.9 \%)\end{array}$ & $\begin{array}{l}\text { selling of property yes } \\
\quad(60.6 \%)\end{array}$ & $\begin{array}{l}\text { selling of property yes } \\
\quad(63.6 \%)\end{array}$ \\
\hline $\begin{array}{l}\text { debenture-bond not } \\
\quad(100.0 \%)\end{array}$ & $\begin{array}{l}\text { debenture-bond not } \\
\quad(94.6 \%)\end{array}$ & $\begin{array}{l}\text { debenture-bond not } \\
\quad(100.0 \%)\end{array}$ & $\begin{array}{l}\text { debenture-bond not } \\
(63.6 \%)\end{array}$ \\
\hline $\begin{array}{l}\text { uncovered bills not } \\
\quad(100.0 \%)\end{array}$ & $\begin{array}{l}\text { uncovered bills not } \\
\quad(100.0 \%)\end{array}$ & $\begin{array}{l}\text { uncovered bills not } \\
\quad(100.0 \%)\end{array}$ & $\begin{array}{l}\text { uncovered bills not } \\
\quad(81.8 \%)\end{array}$ \\
\hline
\end{tabular}

